\title{
DISCLAIMER
}

This report was prepared as an account of work sponsored by an agency of the United States Government. Neither the United States Government nor any agency thereof, nor any of their employees, makes any warranty, express or implied, or assumes any legal liability or reiponsibility for the accuracy, completeness, or usefulness of any information, apparatus, product, or procens disclosed, or represents that its use would not infringe privately owned rights. Reference hercin is any specific commercial product, process, or service by trade name, trademark, manutacturer, or otherwise doek not necessarily constituie or impiy is endurseneni, acumsmendation, or favoring by the United States Government or any agency thereof. The views and opinions of authors expressat herein do not necessarily state or reflect those of the 
TABLE OF CONTENTS

TOPIC PAGE

TITLE PAGE

$\begin{array}{ll}\text { TABLE OF CONTENTS } & 1\end{array}$

I. PROJECT OUTLINE 2

II. PROJECT GOALS, OBJECTIVES, AND STRATEGIES 5

III. PROJECT MANAGEMENT PLAN 9

IV. NARRATIVE SECTION 12

V. RECRUITING METHODS 14

$\begin{array}{ll}\text { VI. INFORMATION ABOUT THE TRAINEES } & 17\end{array}$

$\begin{array}{ll}\text { VII. FAVORABLE DEVELOPMENTS } & 17\end{array}$

$\begin{array}{ll}\text { VIII. CURRENT PROBLEMS } & 18\end{array}$

$\begin{array}{ll}\text { IX. TRAINEE PROGRESS PREPORTS } & 20\end{array}$ 


\section{PROJECT OUTLINE}

The promotion of an aggressive energy research initiative was identified as a goal of the Mississippi. Research Consortium (MRC) from its inception in 1986.

The Department of Energy EPSCoR Program has provided opportunities to address the needs and enhance the interactive programs of energy-related research in the State of Mississippi. The Mississippi DOE EPSCOR Graduate Traineeships Project is a program of education and research which will l) increase the number of trained professionals in the energy sciences and technology, particularly those from groups traditionally under represented in the field, and 2) interface with existing networks of universities, industry, federal, and state institutions involved in energy-related activities.

Key project accomplishments are shown below:

- Statewide Conference on Energy Related Research Held

- HBCU Pipeline Issue Addressed

- Research Preceptors/Problems Selected

- Trainees Screened and Accepted

- Research Initiated

- Practicuns Organized

Mississippi's three comprehensive universities-the University of Mississippi, Mississippi State University, and the University of Southern Mississippi--and the urban institution, Jackson State University, provide a strong foundation for the expansion of energy-related education and research in the state. The activities of the Mississippi DOE EPSCoR Program are being 
executed under a management strategy developed to establish statewide coordination of research and education programs, $i . e$. the Mississippi Research Consortium. The Consortium serves as the steering committee for the DOE EPSCOR Program Consortium.

The Project Director of the Mississippi DOE EPSCoR Program is Dr. David Wertz, Professor of Chemistry and Biochemistry at the University of Southern Mississippi. He is assisted by three cluster leaders, the steering committee, and campus research preceptors. In addition, an Advisory Committee has been formed to provide guidance from representatives of business and industry and federal/state government regarding direction and resources for future energyrelated research and education programs.

The following three research clusters were selected for major emphasis in the Mississippi DOE EPSCOR project because of existing expertise at the MRC Universities. At the same time these three areas allow for active research participation by science personnel at historically black Jackson State University.

- FOSSIL FUEL POLLUTANTS CLUSTER addresses the environmentally sensitive concerns caused by the combustion of fossil fuels, particularly coal and coal products, and ways to minimize the environmentally unacceptable species resulting from use of coal.

- ENHANCED OIL RECOVERY CLUSTER has as its goal the availability of a far higher percentage of our older petroleum deposits.

- pOWER SySTEMS AlND CONSERVATJON CluSTER is directed towards improved efficiency in energy transport and usage. As the project matures, other research areas may be added to these three clusters.

A schematic of the project and jts management plan is presented in Figure One. 
FIGURE ONE

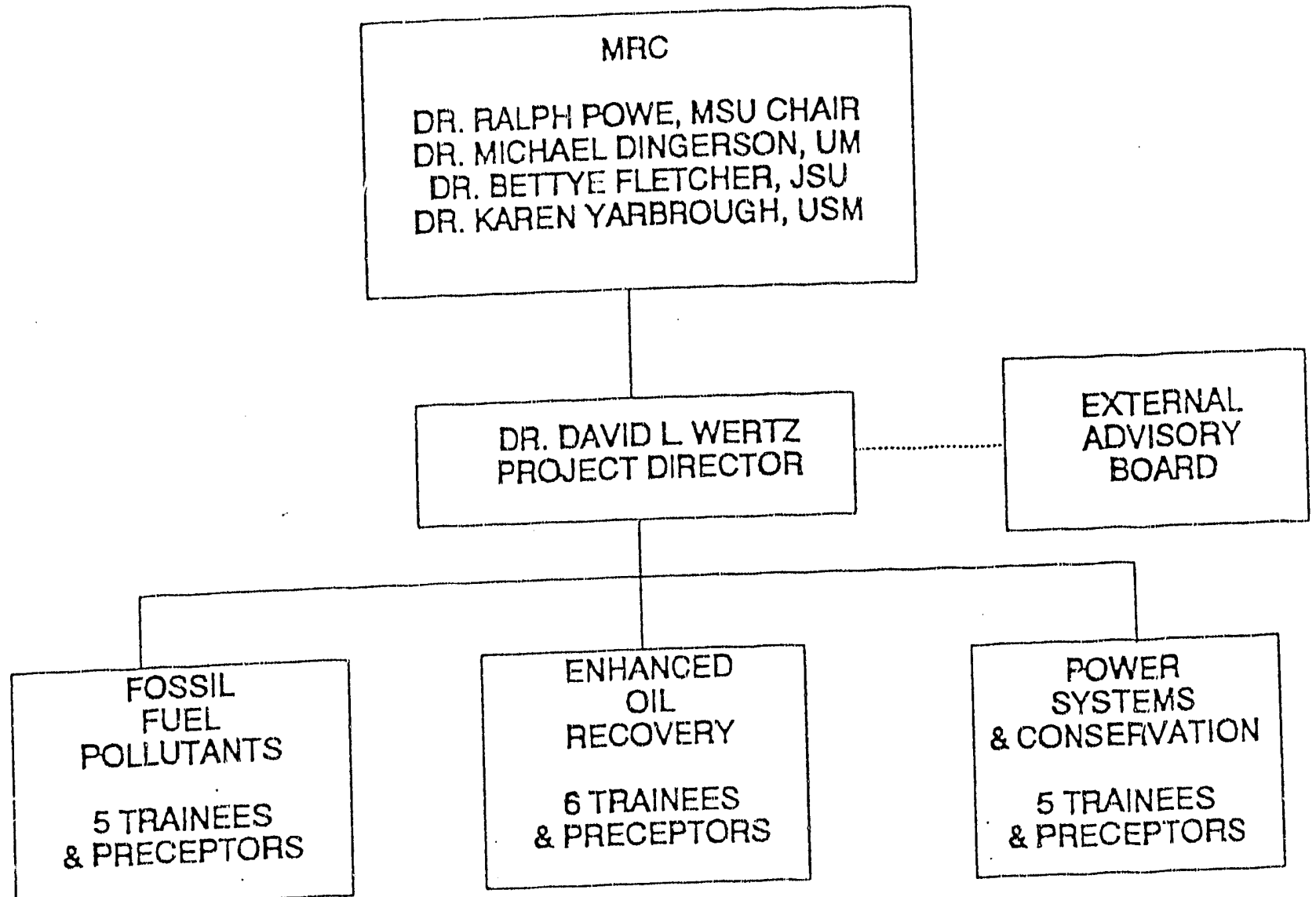


II. PROJECT GOALS, OBJECTIVES AND STRATEGIES.

A. GOALS AND OBJECTIVES.

The goal of the DOE EPSCOR Graduate Trainee project is to provide the appropriate research and educational mechanisms to attract quality scientists and engineers who will contribute to advances in energy research and energy issues. To attain this goal, MRC has selected the following objectives:

(1) To establish an energy research and education program that compliments the needs of this state and the nation;

(2) To create a critical mass of scientists and engineers by incorporating inter-institutional links built around a commonality of research expertise;

(3) To strengthen the state's scientific community by working with other established programs; and by developing the human resource pool to become involved in energy-related research and education;

(4) To establish technology transfer to appropriate user groups by developing stronger research links with other energy-oriented research communities.

\section{B. STRATEG .}

Existing faculty and facilities, with expertise in energy research, are serving as the research preceptors for the Mississippi DOE EPSCOR Traineeship Program. Attracting top graduate students into energy related research projects in Mississippi is now occurring at a much accelerated pace.

To attract the best students by offering competitive stipends of quality educational/research facilities has been the principal strategy employed by the DOE EPSCOR Traineeship preceptors. Naiional advertising by the preceptors has been employed as the principal strategy for bringing the DOE EPSCOR Traineeships 
to the attention of prospective trainees. Excellent stipends have helped make the traineeships attractive to such students and several have already initiated their traineeship activities.

A future strategy will be to bring the master of science graduates from JSU into the appropriate doctoral programs at USM, MSU and/or UM.

C. MEETING THE GOALS AND OBJECTIVES - PROGRESS TO DATE.

After only ten months, fifteen trainees (Table I) have been added to the area of energy research in the state of Mississippi, with at least one more trainee to be added quite soon. This human resource pool represents an initial increase of 408 in energy related research personnel at the graduate level. Since all fifteen are enrolled in graduate courses and seminars at their MRC universities, curriculum emphasis has been reoriented towards energy-related topics. The latter trend will continue and accelerate in each of the participating departments as the DOE EPSCOR project matures and as other DOE initiatives occur.

Although publications and presentations from the Traineeship Program have not as yet resulted, it is clear that the caliber of the trainees is consistent with scientific accomplishments and professional recognitions.

By the Summer of 1993, all of the trainees will have participated in a practicum with an energy related laboratory or industry. That over half of the practicums already have been arranged indicates that acceptance of the Traineeship Program (and our trainees) by the energy community is quite good.

A project dateline is shown in Figure Two. 


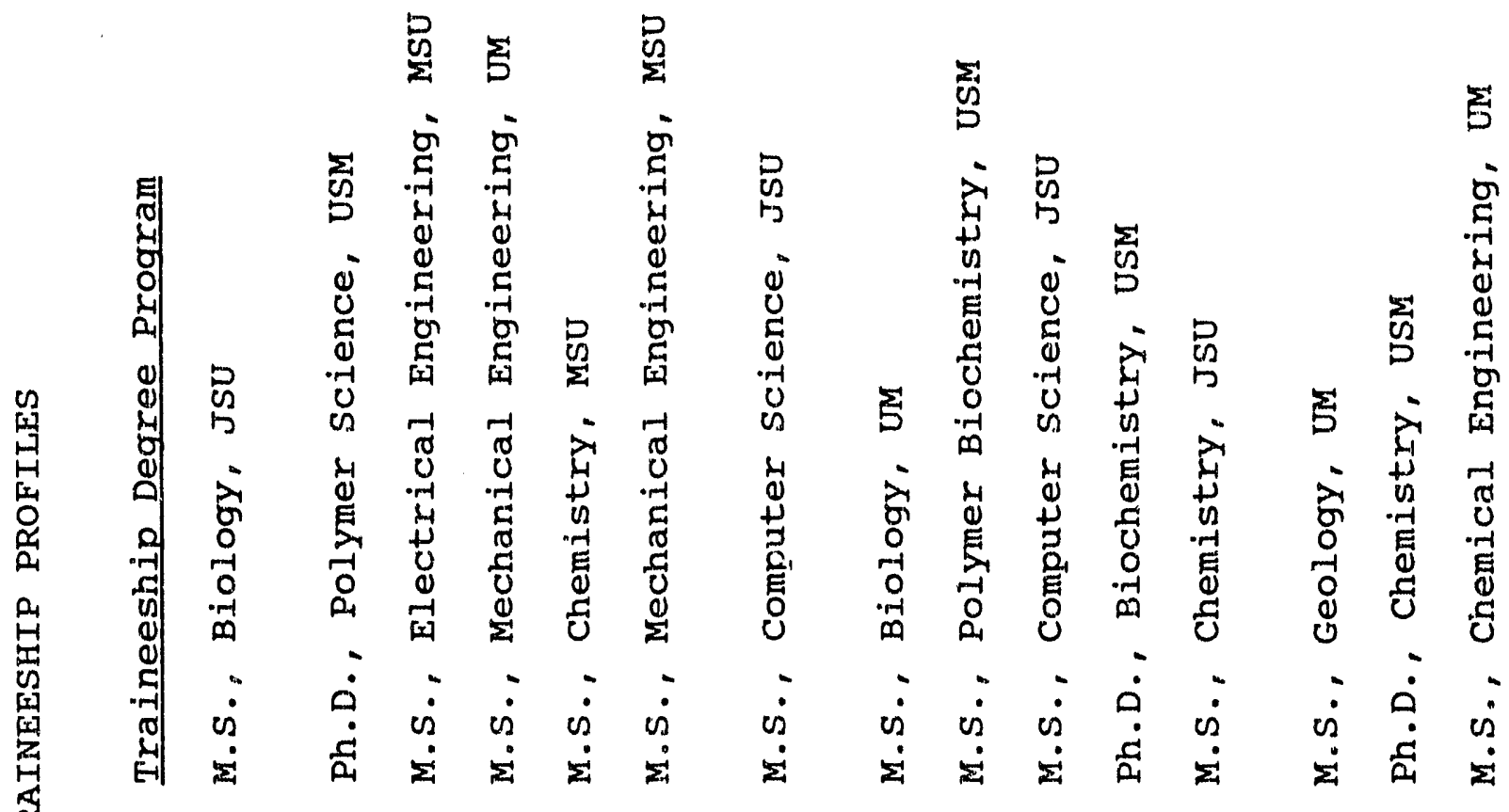

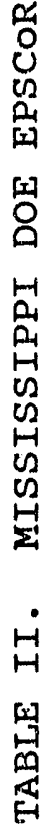

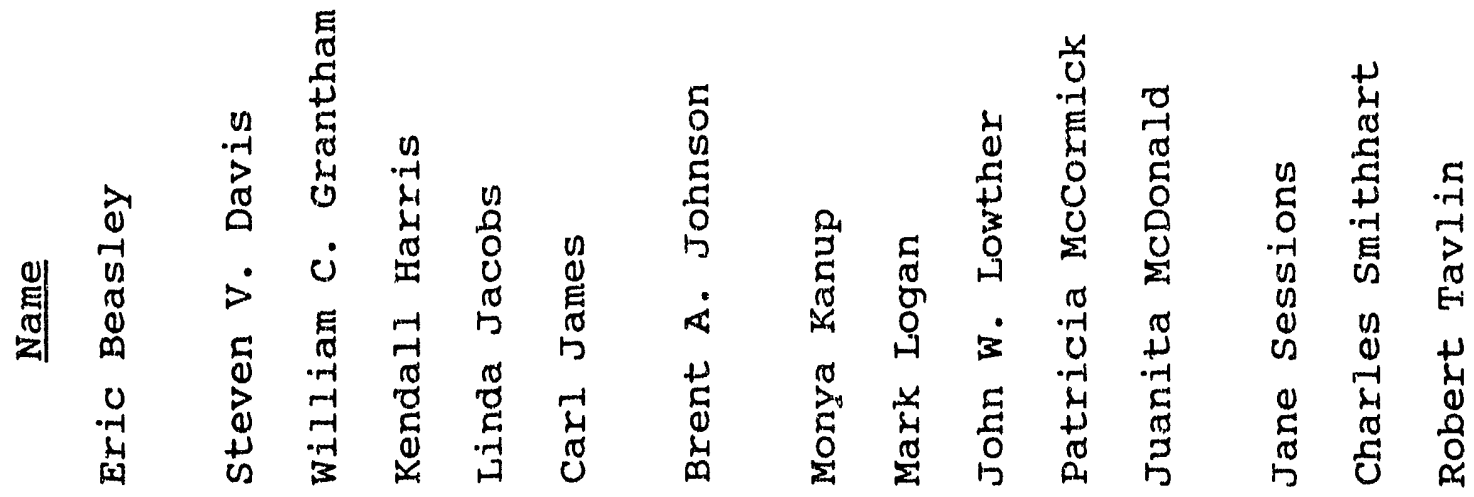

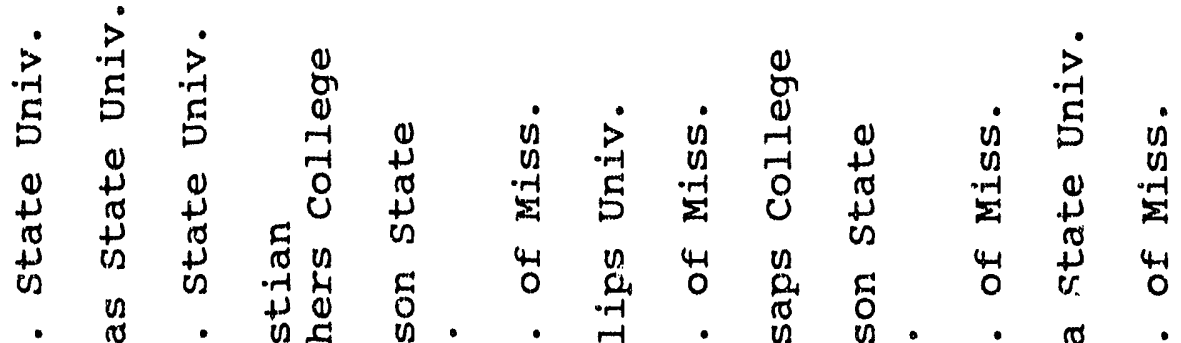

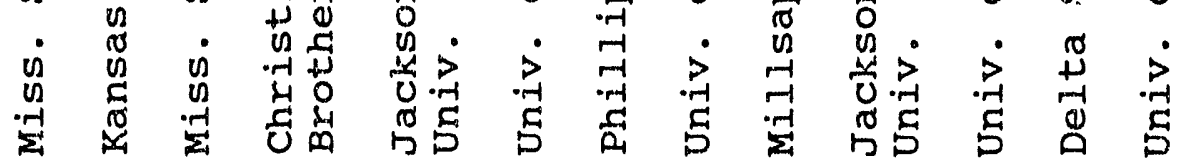

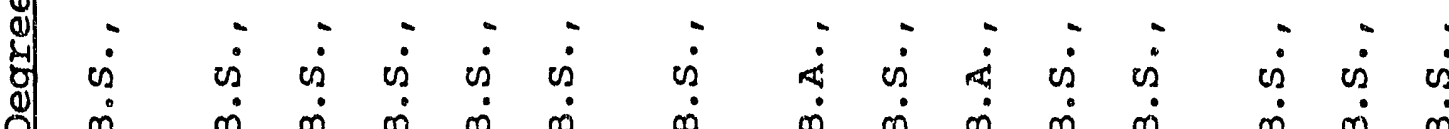

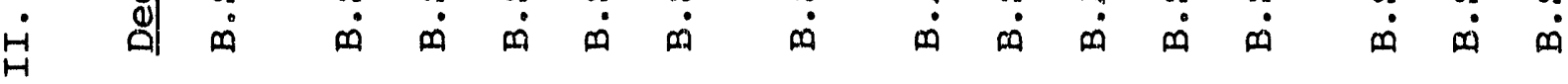


Figute Tivo

\section{MISSISSIPPI DOE EPSCOR TRAINEESHIP \\ PROJECT TIMELINE}

(1991, 1992)

Topic

Q1

Q2

Q3

()+

Fulure

1. Cumen Proposal Funded

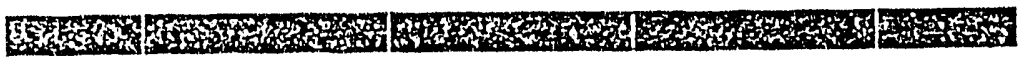

2. Preceptors Selected

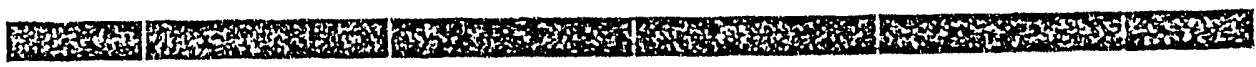

3. Interaction with MRC

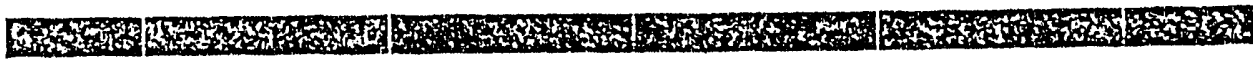

4. Traineship Advertised

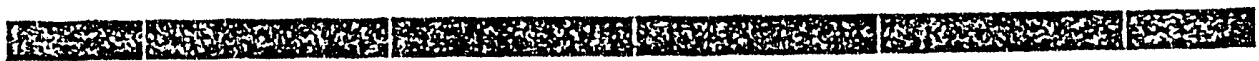

5. Trainees Selected

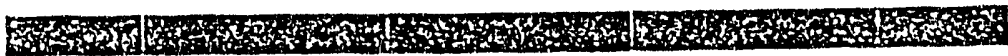

6. Research Begun

F。

7. Monthy Meetings

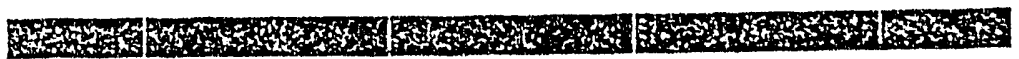

8. State-wide Metings

Max

4.

9. HBCU Issues

10. Practicim Organized

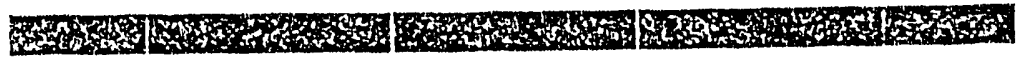

11. External Adrisur Boand

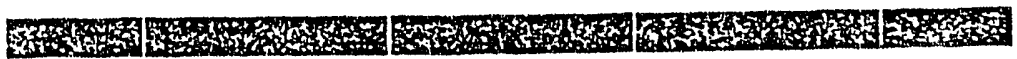

12. Interation with Siale F4 Encrge! Industrics

13. Nationil Moctinges

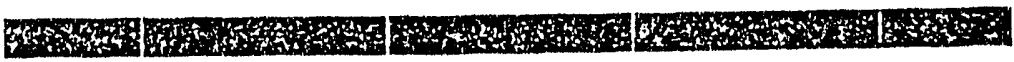

14. Puesentation \& Publications

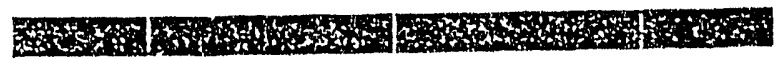


III. PROJECT MANAGEMENT PLAN.

The Mississippi. DOE EPSCoR Committee has designed a management plan to support the administrative requirements as well as the scientific research being conducted by the individual research groups involved in the clusters. This plan (see Figure 1) is based on the organization of project personnel, the mechanisms for program direction and development, and the methods employed for oversight. Cluster research activities have been grouped around themes of current research, strengths within the state, and high national priority. Within each cluster are several research projects with specific goals and objectives and with a specific trainee (selected by that preceptor) who is employed in a graduate degree program and involved in an energy related research project. Personnel in the management structure of the program include the members of the DOE EPSCoR Committee, the Project Director, and the Cluster Leaders.

The MRC Steering Committee is responsible for formulating, implementing and monitoring appropriate strategies and mechanisms to ensure that the chief goal of the DOE EPSCoR program, enhancement of the quality and competitiveness of science in the state, is met. The MRC steering Committee has managed, coordinated, and established policy for this program. It will continue to do so.

A. PROJECT DIRECTOR. The Project Director for the Mississippi DOE EPSCoR Project (Dr. David L. Wertz) has represented the committee in all communications with DOE. The Project Director maintains an effective interface with the Cluster Leaders to ensure rapid, effective communication. Wertz has been responsible for overseeing the three clusters in the program. He has chaired the first quarterly meeting of the committee conducted to receive briefings regarding progress and/or problems encountered and to discuss possible modifications of strategy or allocations of resources. As Project Director, he maintains overall budget 
control. He has devoted approximately $15 \%$ of his time to managing the Mississippi Graduate Trainee DOE EPSCoR Project.

B. CLUSTER LEADERS. The Cluster Leaders ( $\mathrm{Dr}$. David Miller from Mississippi Stare University, Dr. Mark Hardy from Jackson Stare university, and Dr. Robert Woolsey from the University of Mississippi)have assisted the Project Director in organizing and managing the Mississippi Graduate Traineeship DOE EPSCoR Project. The Cluster Leaders have conducted the routine administrative functions of each of their respective programs. The Cluster Leaders have been responsible for collecting and maintaining the data concerning relevant scientific activities of individual scientists and engineers participating in the clusters, for organization of meetings, for development of appropriate materials necessary for the management of the program, as well as insuring the interinstitutional links are solidified. Each made a presentation at the recent onsite visit by DOE staff and consultants (January, 1992).

C. EXTERNAL ADVISORY BOARD. To provide guidance to the MRC and the cluster leaders, an external advisory board has been formed. Asked to serve on the Board are:

1. Larry Hartness

Vice President for Engineerirg

ERGON, inc.

Jackson, MS

2. Mr. William $\mathrm{K}$. Newman

Vice President for Power Generation

Mississippi Power Company

Gulfport, MS

3. Mr. Joseph Sims

Mid Continent $0 i 1$ and Gas Association

Jackson, MS

4. Mr. Wes Miller

Department of Energy \& Transportation

State of Mississippi

Jackson, MS 
5. Dr. Mildred Perry

U. S. Department of Energy

Pittsburgh Energy technology Center

Pittsburgh, PA

6. Dr. Henry F. Hauck*

Louisiana Division

Dow Chemical, USA

Plaquemine, LA

7. Dr. Riitta Ollendorrff

Amoco Research Center

Amoco Oil Company

Naperville, IL

Additional members will be included as the project matures. Each preceptor is continuing to contact potential advisory board members in the areas of his/her expertise.

D. PROJECT PLANNING. The primary vehicle for continued DOE EPSCoR project planning consists of quarterly and semi-annual meetings. The first semi-annual meeting of the research clusters, featuring in-house review of the ongoing research projects, is scheduled for October, 1992, at the Mississippi $R \& D$ Center, Jackson, MS. Each graduate trainee will present both an oral E . FISCAL CONTROL. The University of Southern Mississippi serves as Project Fiscal Agent for the Mississippi DOE EPSCoR Project on behalf of the DOE EPSCoR Committee. The University of Southern Mississippi is the home institution of the

* Dr. Hauck has since been force to resign form the Advisory Committee due to an increase in his assignments with DOW.

and a formal written research/progress review at this and at each subsequent annual cluster meeting. The External Advisory Board members and the MRC Consortium will attend this meeting. 
designated Profect Director, thus selection of this institution as the project fiscal agent facilitates rapid and efficient communication during the course of the program and ensures effective coordination of fiscal matters relating to those components at other institutions in the state.

F. PROJECT REPORTING. The members of the DOE EPSCOR Comittee will review brief progress reports submitted by the cluster leaders to the Project Director at the quarterly meeting of the committee. The Project Director will prepare an annual progress report for use by the comnittee and the DOE Frogram officer. The reporting process described ensures that data on which to base evaluation of the overall progress of the Mississippi DOE EPSCoR Project and of the various clusters is readily avaliable. The date will also provide a guide concerning future actions and any changes in strategy required. The Profect Director wi, J, at the conclusion of the Mississippi DOE EPSCOR Project and, at approprete times, prepare a report describing and evaluating the management techniques and processes used during the Mississippi project. The report will be submitted to the Department of Energy and will be made avallable to other interested partiles. G. MRC UNIVERSITY SUPPORT. Each of the universities is providing tuition and fee support for each of the trainees and released time support for most of the preceptors. USM is providing one additional month of support and extensive travel support to the project manager. Each of the universities is also providing travel for the preceptors to attend the statewide DOE EPSCoR meetings. H. PARTICIPATING DEPARTMENTS AND RROGRAMS

(1) JACKSON STATE UNIVERSITY (JSU) Biology, Chemistry and Computer Science 
(2) MISSISSIPPI STATE UNIVERSITY

Electrical and Computer Engineering, Mechanical and Nuclear. Engineering, Petroleum Engineering and Diagnostic Instrumentation

(3) UNIVERSITY OF MISSISSIPPI

Biological Sciences, Chemical Engineering, Geological Engineering and Mechanical Engineering

(4) INIVERSITY OF SOUTHERN MISSISSIPPI

Chemistry and Biochemistry, Polymer Science and Coal Products Research

IV. NARRATIVE SUMMARY OF PROGRESS.

A. PROJECT DIRECTOR TRAVEL FOR THE EPSCOR TRAINEESHIP PROGRAM.

(1) In November, 1991 Dr. Wertz attended the national EPSCoR meeting in Portland, Maine to represent the Mississfppi DOE EPSCoR traineeship program and to better familiarize himself with the national goals and objectives of the various EPSCOR activities.

(2) In late November, Wertz visited each of the four MRC campuses to discuss the one year grant activities with each preceptor and to facilitate the various start-up procedures. During these visits, Wertz toured several of the laboratories of the faculty preceptors.

(3) In January, Wertz and the cluster leaders fron the DOE EPSCoR Planning Grant participated in a two-day site visit with DOE personnel and a DOE review tean to critlque and strengthen the Mississippi DOE EPSCOR Planning Grant.

(4) In April, 1992 the three cluster leaders and others who will likely be involved in future DOE EPSCOR activities will visit each of the four MRC campuses. During each visit, two principal activities will occur: (a) 
presentations from the cluster leaders concerning future activities will be made, anci (b) current and potential preceptors will provide laboratory tours to illustrate their facilities and capabilities for energy research.

(5) Wertz attended the May 5 and 6 meeting titled "DOE Research Program Priorities and Initiatives" to be held in Washington, DC, along with five other representatives from Mississippi.

(6) Representing the Traineeship Program and also acting a project leader, Wertz attended three meetings in Jackson, MS whers the topics for the State's EPSCoR Research proposal were selected and then fleshed out.

B. THE PIPETINE ISSUE. An excellent opportunity for the Mississippi DOE EPSCoR Project is to attract students from the historically black colleges and universities in this area into energy research :telated graduate programs at the MRC Universities: To accomplish this, at least ten seminars have been given by the various project preceptors to the HBCU's, not only in Mississippi but in several otiver states as well. During each seminar, the DOE EPSCoR Graduate Traineeship Program and its excellent support for graduate energy researchers have been well advertised. As project director, Wertz visited each of the HBCU's in Mississippi (some more than once) during the first year of the project.

C. PROJECT TIMELINE

Shown in Figure Two is a list of key activities for the project.

\section{RECRUITING METHODS UTILIZED TO ATTRACT POTENTIAL TRAINEES.}

A. SEMINARS AND CAMPUS VISITS. Every predominantly minority college and university in Mississippi and most in the surrounding states have been visited by an EPSCoR preceptor in attempts to recruit minorities into the program. The 
DOE EPSCOR Traineeship Program has been discussed with faculty and potential. graduate students during these visits.

B. DISCUSSIONS WITH PREVIOUS RESEARCH COLLABORATORS. Several of the preceptors have had long established relationships with faculty at the Bachelors granting colleges and universities arsund the country. Informal one-on-one discussions about the DOE EPSCOR traineeships have occurred, with good results!

C. ADVERTISEMENTS IN PROFESSIONAL TUURNALS. Four advertisements, submitted to the appropriate national journal(s), are presented in Appendix I.

VI. INFORMATION ABOUT THE TRAINEES CURRENTLY INVOLVED IN THE PROJECT.

The credentials of more than forty candidates have been considered for the traineeships of the Mississippi. DOE EPSCoR Project.

At the present time fifteen (of sixteen) trainees are in place. The sixteenth is expected to join the project in Late August. A brief academic profile of the trainees is provided in Table One. Forty-three percent of the trainees are women, and 368 are black, evidencing a strong interest in energy research and the Mississippi DOE EPSCoR activity from under-represented segments of the higher education population. These high percentages also indicate the success with which the Mississippi DOE EPSCOR Traineeship Program is reaching these under-represented populations. Research and demographic information about the trainees is presented in Figure Three.

VII. FAVORABLE DEVELOPMENTS DUE TO THE TRAINEESHIP PROJECT.

A. VISITING THE CAMPUSES OF THE PARTICIPATING FACULTY PRECEPTORS. The project director, in November, visited each of the participating MRC campuses to discuss the objectives and the specific goals of the project with each of the 
faculty preceptors. Many of the individual preceptors used the visit to review their facilities and their research projects with the project director and to discuss specific problems related to the initiation of each traineeship project.

B. SYMBIOSIS IN FOSSIL FUEL BENEF'ICIATIONS.

During each campus visit, the Fossil Fuel participants met together to develop a symbiotic major theme project while will utilize the characterization expertise of some and the fuel beneficiation expertise of others. Emerging from these discussions is a nationally competitive project involving at least six experts - Cannon, Hussein, Ward, Chen, Cook and Wertz - all of whom were in Mississippi and none of whom were professionally acquainted wi.th their colleagues at the other MRC campuses. This group plans to submit a major proposal soon! Ward (a microbiologist at the University of Mississippi) and Wertz (a physical chemist at the University of Southern Mississippi) are now collaborating on a project which should lead to publication(s). This collaboration would never have occurred without the EPSCoR programs.

C. TRAINEE PRACTICUMS. The practicums that have already been scheduled for 1992 are shown in Table II.

D. SOME FORTUNATE OCCURRENCES. 1. One preceptor has been able to make a "double use" of the trainee stipend. In this situation a terminal year doctoral candidate is being supported at a time when it is critical that he have maximum laboratory time (which the traineeship provides). The preceptor has, however, used the availability of the traineeship in the "near future" to attract an excellent student to his university who will be joining this research group in Fal1, 1992. 2. Quotes from Preceptors. (a) "Without the DOE EPSCoR funds, it would have been impossible to attract a student of $* * * * *$ 's caliber to our 


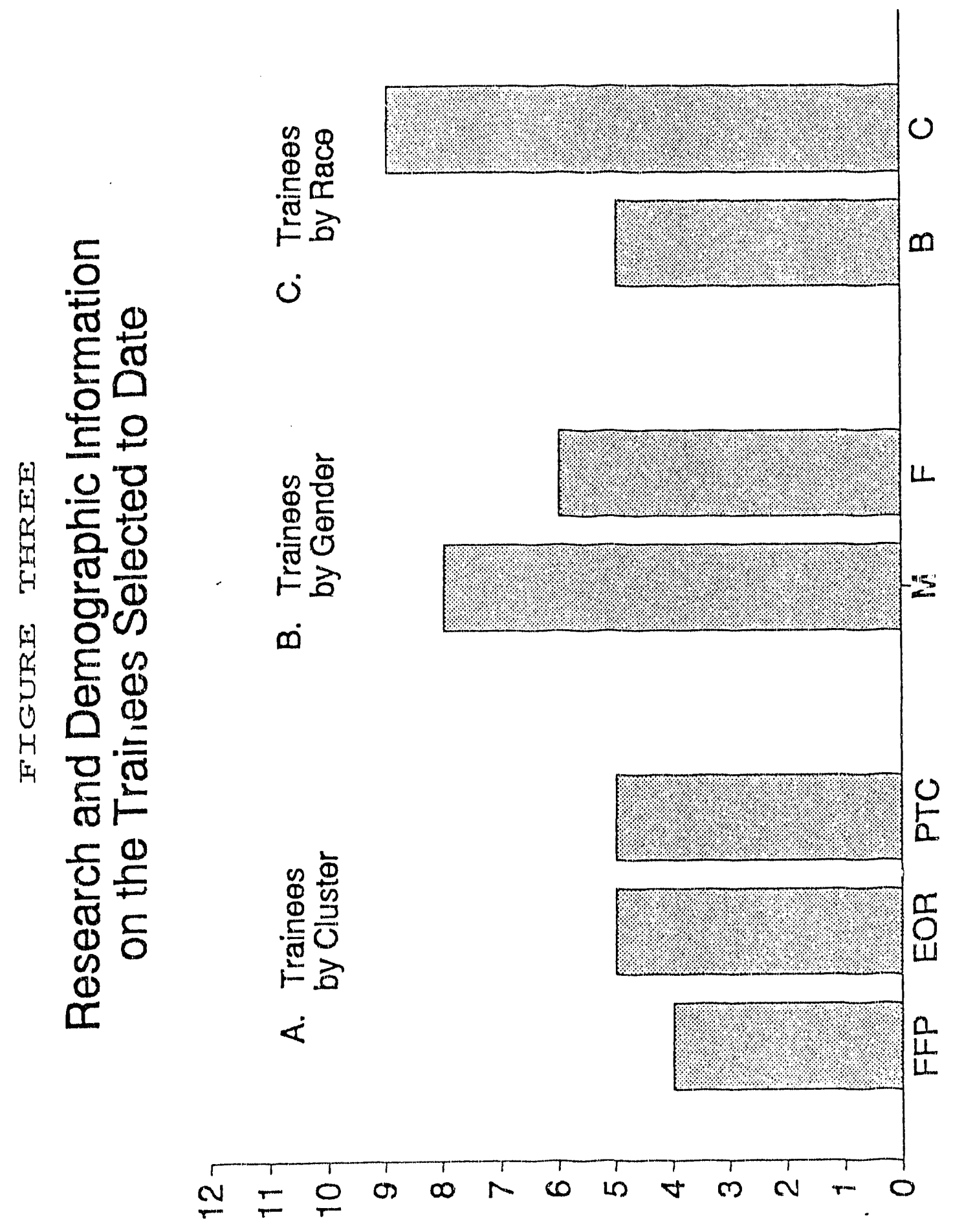


program. (b) The project is off and running with a very positive start - - the organisms now in hand show great potential.

\section{CURRENT PROBLEMS AND/OR UNUSUAL DEVELOPMENTS.}

Timing has been a problem for some of the preceptozs during the first year of the project. Availability of stipend support on october 1 precluded project involvement of trainees on a full-time ba:is during the Fall, 1991 semester because the potential trainees were committed to other activities. Several of the preceptors (see below) were fortunate enough to be able to recruit a trainee for the start of the Spring, 1992 semester.

Other trainees have joined the project at the start of the Summer, 1992 term. The last trainee will be joining for the Fall, 1992 semester.

During the initial period of the project, two of the faculty preceptors -. Dr. Cass Parker and Dr. William Lupton-resigned their positions and left this project. Dr. Wedad Hussein replaced Parker, and Dr. G. S. Jung replaced Lupton. Dr. Hussein, in the Fossil Fuel Pollutants cluster, has introduced the technique of bio-remediation of coal into the overall project theme and has already selected a trainee. Dr. Jung has also selected a trainee and developed a project which compliments other activities in the area of computer pattern recognition applied to energy research.

One serious problem deals with insufficient funds for travel and housing for the trainee during the practicum.

The Mississippi DOE EPSCoR strategy has been to maximize the number of trainees. Thus, because the DOE EPSCOR award was split into sixteen traineeships, here has been minjmal implementation funding for most of the projects. However, because each of the trainees has entered a functioning research 
environment, and the minimal start-up funds (ca. $\$ 4,000$ per trainee) has not presented an insurmountable problem. Nonetheless, the funds for the practiciuns have been difficult to "squeeze" from the traineeship stipends. 
Table II. PRACTICUM ARRANGEMENTS FOR

MISSISSIPPI DOE-EPSCOR TRAINEESHIPS

Irainee

Monya Kanup

Kendall Harris

Charles Smithhart

William Grantham

Steven Davis

Carl Jones

Jane Sessions

Patricia McCormick

Mark Logan

Juanita McDonald

Brent: Johnson

John Lowthex

Eric Beasley

Linda Jacobs

Robert Tavlin

\section{Location}

Idaho National Engineering Lab

Oak Ridge National Lab

Pittsburgh Energy Technology Center

Mississippi Power Company

Sandia National Lab

Dow Chemica1, USA

Heatcraft, Inc.

to be determined later

University of Alabama at Birmingham

Exxon Research Center

to be determined later

Mineral Management Service

Department of Interior

to be determined later

to be determined later.

to be determined later

Exxon Chemical or Pittsburgh Energy Tech Center 


\section{TRAINEESHIP PROGRESS REPORTS.}

A. FOSSIL FUEL POLLiTANTS CLUSTER.

- LINDA M. JACOBS (Cosk). On-Line Analysis of Pollutants from Combustion Driven Facilities by Fourier Transform Infrared Spectroscopy.

After a local search for a recipient of the DOE graduate traineeship, Linda Meschelle Jacobs was selected. Mescheile received her B.S. degree from Mississippi State University in 1991, and is currently working toward a M.S. degree in Chemistry.

Jacobs is enrolled in two core courses and research. During the initial interview process she indicated a desire to be involved in environmental studies and to concentrate in the area of analytical chemistry. Her research project is entitled "On-Iine Analysis of Pollutants from Combustion-Driven Facilities by Fourier Transform Infrared Spectroscopy." The project involves the development of measurement and analysis protocols for the qualitative and quantitative analysis of species at low concentrations ( $\leq \mathrm{ppm}$ ). To date, Meschelle has completed a literature search on multiple-reflection optical configurations which can be adapted for generating the optical pathlengths necessary. She has become familiar with the operation of the FTIR spectrometer, the vacuum system, and the $100 \mathrm{~m}$ cornmercial gas cell. A literature search for the selection of chemometrics methods suitable for the analysis of complicated, multi-component spectra has been initiated. Initial studies involving computer synthesis of spectra from library traces has begun and these will be employed in evaluating the statistical methods.

The results of her work are expected to provide information on pollutant emissions and to provide an evaluation of FTIR as a general purpose on-line diagnostic for fossil fuel facilities. 
- PATRICIA McCORMICK (Cannon). A Study of Recombinantly Modified Organisms for Heavy Metal Detoxification.

In order to genetically engineer cyanobacteria to produce proteins for heavy metal sequestration, DNA encoding the genes for these proteins must first be stably inserted into the bacteria of choice. Progress to date (since September 1991) has included the trainee becoming familiar with bacterial transformation and screening protocols as well as general techniques for manipulation of DNA. The mouse metallothionein gene has been obtained and ligated into a suitable vector for the test organism, Anacystsis nidulans $\mathrm{R} 2$ and the promoter sequence for the tobacco chloroplast psbA gene has been correctly inserted to control transcription of the gene. On going work and future work includes testing the expression levels of metallothionein and the sequestration potential of copper and cadmium by the recombinant organism. We are also investigating the transformation of another cyanobacteria, Spirulina maxima, whose morphology and growth characteristics make it an ideal candidate for use in possible heavy metal sequestration and retrieval processes. The basic molecular biology of $\underline{S}$. maxima has yet to be studied and we are currently attempting to devise a transformation system for the organism.

- JUANITA MDONALD (Hussein). Biodegradation of Sulfur in Coal.

The trainee student joined my group only in February, 1992. So far, we are gathering literature information about the project. The following is a summary of the idea behind the proposed research.

The sulfur present in coal is conmonly classified as organic and inorganic. The organic sulfur is chemically bonded to the hydrocarbon matrix of the coal while the inorganic sulfur is imbedded in the coal mainly a sloose pyrite. Five 
functional groups of organic sulfur are known to exist in coal: mercaptan or thiol, sulfide or thio-ether, disulfide, aromatic thioring and thiopyrone. Inorganic sulfur occurs mostly as iron disulfide and to a smaller extent as sulfates of iron, calcium and barium. Several bacteria such as "thiobacillus" can use the reduced sulfur as a source of electrons and energy for biosynthetic reactions. The biological oxidation of reduced and elemental sulfur is largely brought about by the action of sulfur oxidizing iithotropic bacteria. These fall into two groups, both of which are able to utilize carbon dioxide as the sole carbon source: 1) The colorles chemosynthetic sulfur oxidizers, generally aerobes, utilize electron flow from reduced sulfur compounds to oxygen or to nitrate for the anaerobic strains. This is coupled to respiratory chain phosphorylation to generate the reducing power of carbon dioxide assimilation. 2) The photosynthetic purple and green sulfur bacteria that utilize reduced sulfur compounds for carbon dioxide assimilation in the presence of light and absence of oxygen.

Plans for the next two years - Bacteria will be grown in our laboratories which is equipped with needed facilities. Later on, sulfur reducing enzymes might be isolated and immobilized to increase the efficiency of sulfur removal from coal.

- CHARLES SMITHHART (Wertz). Speciation and Abundance Measurements of Pollutants in Fossil Fuels.

Smithhart, a doctoral candidate, has measured the very small changes in the wavelength-dispersive $x$-ray emission spectra of sulfur in various oxidation states $(-2,0,+6)$. The samples have included $\mathrm{FeS}, \mathrm{FeSO}_{4}, \mathrm{~S}_{8}$, and combinations of the three. The ability to provide speciation of sulfur 
forms in coals is des:rable since this information may lead to optimized desulfurization methods. Various combinations of monochromators, collimators, and signal processing have been employed in order to find the optical and electronic arrangement best suited for these measurements; results thus far seem promising.

Unfortunately, the very small energy changes involved can be easily overshadowed sy temperature effects, instrumental errors and sample surface inhomogeneities; a large number of high-resolution scans must therefore be performed in order for the results to have any statistical signifigance. Computer code for multiple-signal averaging has been written and deconvolution software employed in order to overcome the inharent lack of sufficient resolution. Future research will concentrate on standardizing the sample preparation technique and applying the method to previously characterized coal samples.

Analysis of resid samples (from the Consol Program) and of microbially treated coals have also been performed.

Smithhart attended the National American Chemical Society and its Fuel Science Division Meetings in August, 1992.

-ROBERT LAVLIN (Chen). Nitrous Oxide Formation and Destruction in Fluidized Coal Combustion.

Since the official notification of the program award in December, 1991, the activities of this program include student recruitment, design and fabrication of a fluidized sand bed, and numerical modeling.

A recruiting advertisement was placed in Chemical Engineering Progress in January, 1992. The program announcement was also mailed to about 100 Chemiral 
Engineering Departments around the nation in December. The preceptor has chosen Mr. Robert Taviin as the trainee for this program. A number of contacts for the trainee's laboratory practicum with an energy industry or with a DOE multiprogram laboratory have also been made.

The fluidizld sand bed under construction consists of a $30^{\prime \prime}$ long, 2.5" inside diameter ceramic tube $\left(99.8 \% \mathrm{Al}_{2} \mathrm{O}_{3}\right)$ with a bed height about $6 "$. An electric furnace is able to heat the same bed up to $1150^{\circ} \mathrm{C}$. Basket of coal sample is dropped into the preheated sand bed and products are analyzed by online $\mathrm{NO}, \mathrm{NO}_{2}$, and $\mathrm{N}_{2} \mathrm{O}$ analyzers. For coal fragmentation study, coal's void fraction (as an index of fracture propagation) and chemical changes (e.g., water and carbon content) w.11 also be investigated.

The model under development contains a number of elements. A coal pyrolysis model developed earlier by this author will be used in this element of the model. It was assumed that coal undergoes primary devolatilization to liquids, and liquids undergo competitive secondary recondensation reactions to higher molecular weight compounds or decomposition reactions to lower molecular weight compounds. The second major element in the model involves pressure-induced shattering. Fragmentation will be assumed to be caused by volatiles built up in the coal particle, and the stochastic fragmentation model established by others will be employed. In the submodel of gas/solid reactions, it is assumed that the delayed nitrogen evolution is governed by the rate of burning of char particles; i.e., the total nitrogen to $\mathrm{HCN}$ is proportional to carbon evolution. In addition, $\mathrm{HCN}$ undergoes catalytic reaction to $\mathrm{NH}_{3}$ in the char. Finally, the gas phase reactions involves dividing the reactor into a series of plug flow reactors and the complex reaction pathways can be conducted based on Sandia's CHEMKIN package. At the time of this writing, two manuscripts on stochastic modeling of 
coal fragmentation and tar molecular weight distribution during pyrolysis thave been subritted to the upcoming annual AIChE meeting.

\section{B. ENHANCED OIL RECOVERY CLUSTER}

- Carley and Sawyer. $\mathrm{CO}_{2}$ Enhanced 011 Recovery Designated for the Southeastern United States.

The research to be accomplished by the trainee will deal with enhanced oil recovery using carbon dioxide.

Most of the oil reservoirs in Mississippi are older and, to maintain production, are in need of enhanced recovery techniques. Mississippi has a large reservoir of $\mathrm{CO}_{2}$ in the Jackson Dome. The use of this resource to increase production would be significant economic benefit to the state.

However, the compatibility of $\mathrm{CO}_{2}$ with the various oils in Mississippi reservoirs is unknown. Alsu, there are no standard, reliable methocls for predicting the flow of a multiphase fluid in porus media.

These topics will be addressed by the trainee using the newly installed Carbon Dioxide Enhanced 011 Recovery Laboratory in the Petroleum Engineering Department at Mississippi. State University. This state-of-the-art laboratory has been installed and all equipment and instruments checked out. The calfbriation phase has started using oil and lock samples from Mississippi reservoirs.

During the next two years a variety of Mississippi reservoir fluid: and rocks will be tested for compatibility to $\mathrm{CO}_{2}$ flooding methods of enhanced oil recovery. 
- BRENT A. JOHNSON (Davis), Oil Spill Response Preparation. The Use of GIS.

The objective of this project is to devise a geographical information system (GIS) methodology to enhance oil spill recovery and response. In effect, the project has been split into two modules: a GIS module and an oil spill response/recovery module. Efforts are being made in both of these modules en route to constructing a seamless synthesis of the two. Johnson has just begun working with the project and learning GIS technology, functionality, and applicability. This is being accomplished by acquiring a broad understanding of current GIS technological trends and applications through GIS publications and technical papers; digesting Information from selected texts on the subject and compounding knowledge of GIS to tallor our in-house system (ARC/INFO) to project specifications.

The construction of the oil spilil response/recovery module is being developed through consultation with personnel at the Mineral Management Service (Department of the Interior) concerning the most effective application of GIS technology to the current ofl spill response/recovery system; becoming familiar with the fundamentals of various techniques of ofl splil response and recovery through various publications and consulting with organizations actually participating in oil spill response/recovery e.g. the Coast Guard.

The next year will involve comprehensive information gathering for the design and development of specialized descriptive and spatial database(s) and the merging of the oil spill response/recovery strategies to the actual implementa. tion of a GIS methodology. 
- MARK LOGAN (McCormick). Advanced Polymers for Enhanced Oil Recovery.

Currently, molecular cloning techniques are being utilized in the synthesis of a novel biopolymer \protein. By employing this method the exact placement of every monomer in the resulting biopolymer may be precisely controlled. Through the precise control of polymer structure and the incorporation of hydrophobic interactions and columbic interactions, polymers displaying precise physical properties may be constructed. The design considerations of these biopolymer/proteins are such that both hydrophobic and hydrophilic sequences, designed to bring about $\mathrm{pH}$ responsive hydrophobic interactions, have been employed.

At this time the DNA encoding for a novel biopolymer,protein has been synthesized and characterized. Several different strategies for the eventual expression of this biopolymer/protein are currently being investigated.

Upon the successful expression of this protein, structure-property relationships will be developed. This information will be utilized to maximize specific interactions and properties in subsequent polymers produced in this manner. The overall goal being the synthesis of polymers which display hydrophobic microdomain formation while maintaining chain extension and other appropriate properties lior enhanced oil recovery(EOR).

- JANE SESSIONS (Van Besien). G/S-Based Exploration Models for Mississippi.

Due to the late award of the EPSCoR Grant, difficulty was experienced in selecting the trainee; available graduate students were already committed to funding. Jane sessions, who joined the program at the start of the spring semester, has now been selected as the trainee for this grant and will begin project activities during the sumer semester. Initial activities will include familiarization with the remote sensing and geographic information systems 
software. The trainee will familiarize herself with the geology of Mississippi hydrocarbon discoveries and begin studies for selecting candidate scenarios for geographic information systems. Based on the sites selected the trainee will begin assembling geologic and geophysical data for incorporation into the geographic information system.

- MONYA KANUP (Ward). Microbially Enhanced Oil Recovery.

Beginning about mid-January ('92), Monya Canup began work as the Trainee under my direction. Through the date of this report, we have screened about twenty cultures (some pure and some mixed) for MEOR activities, with an initial focus on bioemulsification and biodegradation of crude oil under conventional or simulated MEOR conditions. We have obtained about one dozen cultures that exhibit good MEOR activity on a Mississippi light crude oil. Each of these organisms will use the oil as a carbon source, and several also show good bioemulsification activity. There is visual evidence that different organisms act differently on the oil. We also obtained isolates from a working Mississippi oil well (McComb field) that had on-site oil and brine contamination. From the brine/oil, soil/water mixture, we isolated cultures that exhibit good MEOR activity at up to 108 salinity. During the next several months, we will begin to characterize the new isolates further, and to collect new samples for screening, During the next two years, each culture showing potential for MEOR applications will be tested for activity under a variety of MEOR conditions. Each superior culture will be assessed for mechanism(s) of activity on oil; e.g., extracellular vs. cell-bound catalysts, chemical identity of the active agents, stability of activity, and optimum or high-stress conditions. Attempts will be made to correlate laboratory MEOR activity with field applications. 
C. POWER SYSTEMS \& CONSERVATION CLUSTER.

- ERIC BEASLEY (Hardy). Biofertilizer Technology: An Alternate Source. Beasley was selected as the trainee for this project in late 1991. He has begun work and has completed one experiment on the microalgal biofertilizer problem. We are excited with the results because we have generated NMR spectroscopy data from salt-stressed microalgae. Accurate interpretation of this data will qualify and quantify the type of organic compounds that have accumulated as a result of the high $\mathrm{NaCl}$ environment in which the microalgae were grown. Eric has leaxned laboratory techniques that allow him to perform these experiments without introducing a great deal of contamination. He has also assisted in tutorial programs designed around this project for undergraduates interested in research.

The NMR analysis is being done in the Department of Chemistry with the assistance of Dr. Richard Sullivan, Chair of the Department of Chemistry, and his graduate assistant. Spectral analysis will be included in the final report. Eric is learning the NMR techniques from them.

Eric attended the Mississippi Academy of Sciences Meeting this year (February, 1992). There he interacted with students and faculties from the universities in attendance. He observed the techniques of paper presentations and poster presentations so that he could incorporate some of these ideas into presentations he is preparing.

We are now continuing our work and ordering more supplies for the laboratory. Eric is also working with Dr. Sullivan's graduate student in preparing the samples for NMR analysis (which is a technique that is non-evasive and allows the cells to be used as inoculum for further experiments). 
- WILLIAM GRANTHAM (King/Miller). Application of Solid-State Control Components and Neural Networks for Rapid, Intelligent Series Capacitance Control of Transmission Lines for Improvement of Power System Stability and Efficiency. The research is focusing on a new system for control of power flow on an electric power transmission system. The new control technique utilizes solid state control devices to enhance voltage levels, minimize losses, and direct the flow of power on the transmission system. The electric power industry refers to this system as FACTS (Flexible AC Transmission System). The principal components of FACTS are static VAR compensators, series capacitors, and phase shifters.

Research to date has concentrated on familiarizing the trainee with the problem. A literature review has enabled the trainee to become very familiar with the state-of-the-art in the use of FACTS. A tangible result of this work will be a report summarizing the findings. This report will also include some preliminary computer simulations that the trainee is using to acquaint himself with the concept of power flow on a transmission system and how it is impacted by FACTS devices.

As the research continues, we will investigate the characteristics of actual gate-turn-off thyristors (GTOS) in the laboratory to ensure that we have a good model of their switching chaxacteristics. Then, we will develop neural networks to identify and respond to changes in the system. Finally, we will perform simulations that incorporate the measured GTO characteristics and neural networks to determine if the control system will achieve the desired improvements in system and efficiency and stability. We will also identify any undesirable side effects which might be manifested by the GTO switching that would detract from the overall system improvement. 
- KENDALL HARRIS (Roux). Conservation of Thermal Energy via Coupled Conduction, Radiation and Mass Transfer in Fiberous Insulacions.

In January 1992, Mr. Kendall Harris joined Ole Miss as a graduate student in the Mechanical Engineering Department; Mr. Harris is presently a trainee on this project. He has made a strong contribution to the project in the short time since he has joined the project. Good winter time data has been collected since last fall. Presently this data is being plotted and analyzed by Mr. Harris. The use of a foil radiant barrier is having a significant impact on reducing the heat transfer through the celling insulation. Data is being collected for four test batts of R-19 fiberglass insulation both with and without foil radiant barriers. The data is being collected from heatflux meters, temperature sensors (type $J$ thermocouple and relative humidity meters. These sensors are being sampled every 15 minutes on a 24 hour basis for a wide variety of climatic conditions. Mr. Harris has begun processing the data and as a result of his analysis some changes in the sensor placement have already been initiated. In parallel with the experimental measurements of heat flux, temperature, and relative humidity, an effort to numerically model the heat and mass transfer is also underway. The development of the numerical model and the data acquisition will be ongoing for a long term duration.

During the next two years, the project will investigate a number of attic insulation types and configurations. The configurations will be both with and without foil radiant barriers, with and without forced ventilation, various thickness of insulations (R-11, R-19, R-30), clean and dusty foil, dry and high humidicy attic conditions, and different types of insulation (fiberglass, rockwool, ar cellulose). The future agenda is full and the prospects for developing a better understanding to optimize and tailor insulation applications 
is good. The results of this research should lead to clear cut approaches for conserving energy and reducing air pollution.

- STEVEN V. DAVIS (Mauritz). Ionomer Membranes and Ionomer-Based Microcomposite Membranes for Fuel Cells and Other Uses.

Nanocomposites were formulated via the sol-gel reaction for tetraethoxysilane in the nanometers-in-size polar clusters of perfluorosulfonate membranes. The degree of connectivity of $\mathrm{SiO}_{4}$ tetrahedra in the in situ-grown $\mathrm{SiO}_{2}$ phase was probed with ${ }^{29} \mathrm{SI}$ NMR and IR spectroscopies. Initially, membranes were in the $\mathrm{SO}_{3} \mathrm{H}$ form prior to the sol-gel reaction. Later, we incorporated metal salts (e.g. $\mathrm{AgNO}_{3}, \mathrm{Pt}-, \mathrm{Cu}-, \mathrm{Fe}-, \mathrm{CoCl}_{2}$ ) either before or after the sol-gel reaction and the cations reduced by passing $\mathrm{H}_{2}$ through the membranes. Gas permeabilities (P) of the membranes were determined and $P$ vs pressure ( $P$ ) relationships suggest dual mode sorption at low $\mathrm{p}$, but $\mathrm{P}$ becomes enhanced at higher $\mathrm{p}$; the curves are depressed overall on the second run indicating structural changes with permeation. In progress are $\mathrm{P}$ vs $\mathrm{p}$ studies as a function of $\mathrm{SiO}_{2}$ content and metal type. Light microscopy indicated nanocomposites having high $\mathrm{SiO}_{2}$ levels can have surface-attached layers; at low levels all $\mathrm{SiO}_{2}$ is in the bulk.

Sol-gel-deprived mixed oxides (e.g. $\mathrm{SiO}_{2}-\mathrm{TiO}_{2}, \mathrm{SiO}_{2}-\mathrm{Al}_{2} \mathrm{O}_{3}$ ) will be generated in membranes using appropriate alkoxides, some being metallized as before. oriented particles will be grown in uniaxially-deformed membranes. Postannealing will control the ultimate degree of $\mathrm{SiO}_{4}$ connectivity. Membranes will be screened for gas permselectivity, anticipating energy-efficient separations applications (e.g. $\mathrm{O}_{2} / \mathrm{N}_{2}, \mathrm{CH}_{4} / \mathrm{CO}_{2}$ ). Microstructure will be explored using multinuclear NMR/FTIR/dielectric relaxation spectroscopies, and DSC/TGA thermal analyses. Mechanical tensile/DMA (relaxation) analyses will yield information 
regarding material strength and inorganic phase percolation. SAXS/SANS studies (w. Sandia Labs.) will provide information on interfacial and long range structure.

- CARL JAMES (Hodge). Development of Experimental Techniques for a High Temperature Energy Storage Test Facility.

During the Fall 1991 Semester the Mechanical and Nuclear Engineering Department (MNE) at MSU identified and brought on board an EPSCoR trainee and refined and developed a DOE EPSCOR research thrust area in Power Transmission and Conservation. Additionally, exploratory discussions have been held with Dr. Jeff Roux of the University of Mississippi (UM) Mechanical Engineering Department about the possibility of involving UM faculty in the research thrust area. The DOE EPSCoR research thrust area of the MNE Department at MSU, with possible involvement with UM, will be centered around experimental and computational aspects of advanced heat exchanger design and application. The MSU MNE DOE EPSCOR team has initiated both industrial and national laboratory contacts in this area. A critical cadre of faculty interested in the thrust area has been assembled. The MSU MNE team members include Dr. Roger Briley, Dr. B. K. Hodge, Dr. Jim Stevens, and Dr. R. P. Taylor, and Dr. Jeff Roux from UM has indicated interest. Heatcraft, Inc, of Grenada (MS), one of the larger manufacturers of finned-tube heat exchangers, has indicated an interest in the topics proposed for the heat exchanger research thrust area. The team intends to pursue at least an advisory relationship with Heatcraft as they are cognizant of research needs in the industry. Two members of the team, Taylor and Hodge, have recently completed a research contract with DOE's Argonne National Laboratory, and Argonne has 
agreed to fund further phases. The trainee's MS thesis topic will be a portion of the next phase of the research from Argonne.

- JOHN W. LOWTHER (Jung). Responses to Energy Industry Emergencies Using Graphical User Interfacing.

Efficient response to a specified energy industry emergencies in open waters requires consolidated information concerning a variety of parameters such as nearest landfall, nearest port, location of energency response facilities, etc. Retrieving and using such information for decision making requires human expert's experience and knowledge. In this project, we investigate decision support system for helping human expert's decision upon various emergency situations. The decision support system can assist a human expert in the design of response scenarios in the preparation of real-time events.

The project consists of two phases. In the first phase, Lowther will. develop user-friendly graphical user intertace (GUI) for retrieving useful information from the systern, and for dialoguing with the system interactively. The GUI for decision support system consists of several windows for displaying geographical/seismographic images and corresponding text files, and of dialogue boxes for interaction between the system and a user. The trainee has been involved in developing the GUI running under MS windows using window development tools. A part of the prototypical GUI has already been implemented.

In the second phase, we plan to investigate effective and efficient methods of representing images and factual knowledge in a unified way through spatial analysis and modeling of geographical data. Inference mechanism for extracting new factual knowledge from the existing knowledge base, and for drawing 
conclusions with respect to a user's query will also be investigated. These issues for the second phase will be investigated in the next two years. 

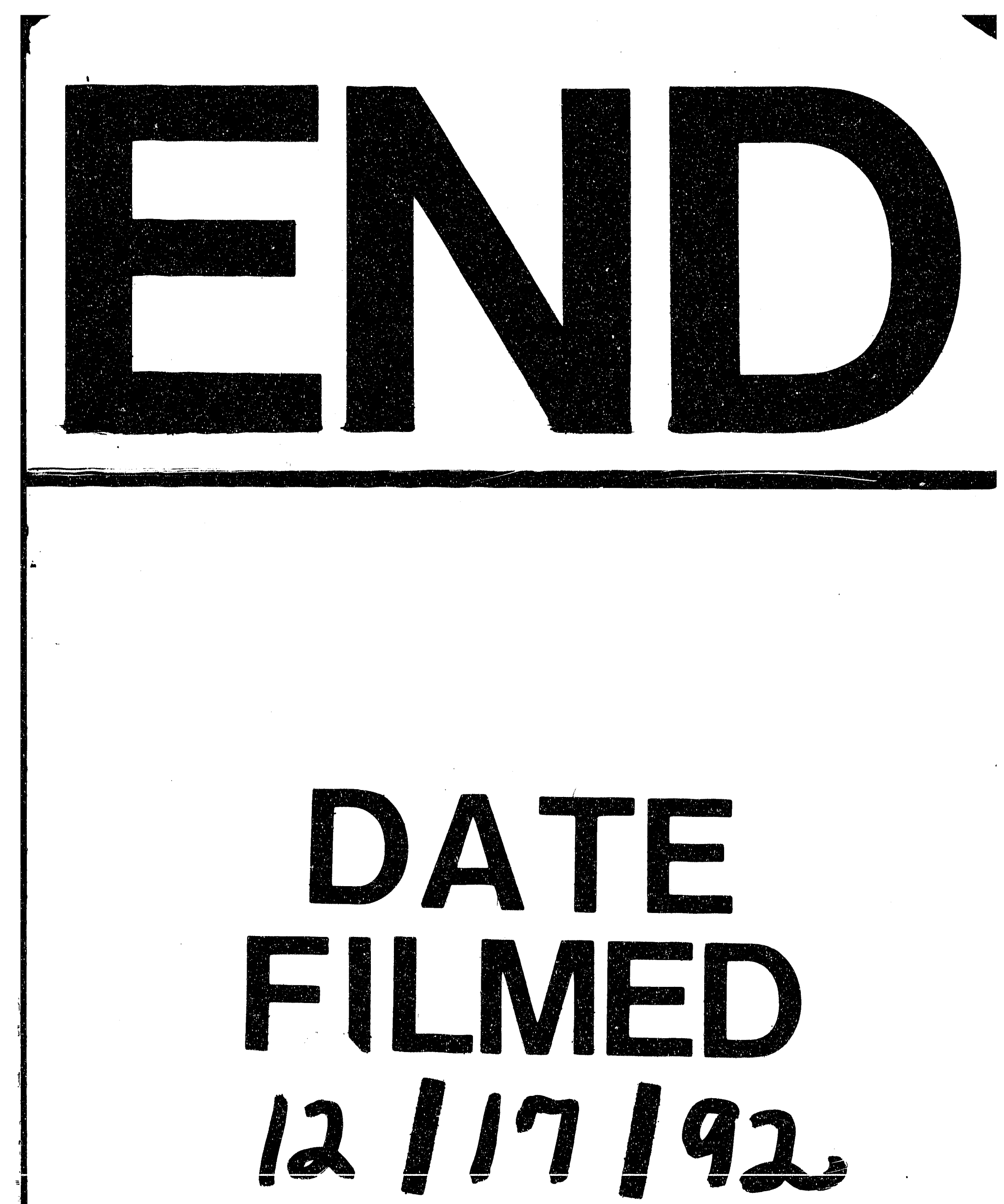
